\title{
KONSEPSI PERSEPSI MANFAAT DALAM KETERLIBATAN KONSUMEN TERHADAP KEBARUAN PRODUK
}

\author{
Ignasius Heri Satrya Wangsa ${ }^{1^{*}}$, Maria Josephine Tyra ${ }^{2^{*}}$ \\ ${ }^{1,2}$ Program Studi Manajemen, Fakultas Bisnis \& Akuntansi, \\ Universitas Katolik Musi Charitas \\ Jalan Bangau No. 60, Palembang 30113 \\ *Corresponding Author: ig_heri@ukmc.ac.id ${ }^{1}$, tyra@ukmc.ac.id ${ }^{2}$
}

\begin{abstract}
The competitive business environment demands innovative efforts to create product newness. Within consumer-oriented goals, the business should create a recognizable product newness. Consumption in economic rationality is the consumption of benefits. Therefore, recognizable product newness occurs when the product itself is perceived to be beneficial. This research resulted in two basic concepts of perceived-benefit of product newness through consumer involvement, namely experienced-driven benefit and economically rationalized benefit. This research is expected to contribute to the theories of perceived benefit, consumer involvement, and product newness.
\end{abstract}

Keywords: perceived benefits, consumer engagement, product novelty.

\begin{abstract}
ABSTRAK
Lingkungan bisnis yang kompetitif menuntut upaya inovatif menciptakan kebaruan produk. Dalam pandangan orientasi konsumen, bisnis menciptakan kebaruan produk yang dapat dikenali. Konsumsi dalam rasionalitas ekonomi adalah konsumsi manfaat. Oleh karenanya, kebaruan produk yang dapat dikenali terjadi ketika produk itu sendiri mampu dipersepsi bermanfaat. Penelitian ini menghasilkan dua konsep dasar persepsi manfaat terhadap kebaruan produk melalui keterlibatan konsumen, yaitu konsep manfaat yang dikenali dari pengalaman dan konsep manfaat yang berasal dari rasionalitas ekonomi. Penelitian ini diharapkan memberi kontribusi terhadap teori persepsi-manfaat, teori keterlibatan konsumen, serta teori kebaruan produk.
\end{abstract}

Kata kunci: persepsi manfaat, keterlibatan konsumen, kebaruan produk.

\section{PENDAHULUAN}

Dalam lingkungan pasar kompetitif bisnis selalu berusaha eksis dengan melakukan inovasi produk. Pengertian inovasi menempatkan produk untuk selalu dibuat baru. Kebaruan produk ini relevan dengan selera konsumen yang dinamis. 
Bagi bisnis rasionalisasi strategi kebaruan produk adalah menarik minat dan kesadaran konsumen dengan menawarkan produk yang memiliki nilai beda (Martin and Morich, 2011). Konsekuensinya adalah konsumen yang dikondisikan untuk selalu mengikuti sekaligus menyesuaikan dengan tren kebaruan produk. Bloch et al. (2009) menyebutkan hal ini sebagai keterlibatan konsumen terhadap produk. Keterlibatan semacam ini memiliki tingkatan untuk setiap produk yang berbeda (Michaelidou and Dibb, 2006). Zaichkowsky (1986) dalam Lin et al. (2013) mendefinisikan keterlibatan produk sebagai persepsi seseorang terhadap sebuah obyek menurut kebutuhan, nilai serta minat yang dimilikinya. Keterlibatan konsumen berpengaruh terhadap dinamika dan kualitas proses pengambilan keputusan konsumen (Kinard and Capella, 2006). Konteks ini menuntut bisnis untuk tanggap yakni perlunya dikembangkan keterlibatan konsumen menemukan manfaat produk (Dinnin, 2009). Oleh karenanya, kebaruan produk dalam persepsimanfaat adalah keterlibatan konsumen di mana proses informasi dan pembelajaran berlangsung meliputi: melihat (to see), merasakan (to feel), mengalami (to experience), dan merekomendasi (to recommend) dilandasi oleh pengertian produk yang adaptif terhadap kebutuhan konsumen (Cummins et al., 2014).

Kebaruan bersifat adaptif dan praktis untuk dapat diterima oleh konsumen sejauh persepsi-manfaat terbentuk (Dinnin, 2009). Pandangan ini mengantar kepada pengertian keterlibatan konsumen dalam proses pengenalan untuk menemukan manfaat produk. Ini mendasari kebaruan produk yang tetap berorientasi pelanggan (customer-centrix). Nilai strategis dari kajian ini adalah menyediakan referensi bagi pengertian persepsi-manfaat dalam keterlibatan konsumen terhadap kebaruan produk.

Untuk mendukung penelitian ini maka dipilih Produk "X", yaitu aplikasi kelas virtual yang diterapkan sebuah PTS di Kota Palembang. Produk "X" dipakai untuk merepresentasikan kebaruan produk. Penggunaannya dimulai sejak bulan September 2020 sebagai sarana perkuliahan untuk memfasilitasi interaksi pembelajaran dosen-mahasiswa secara virtual selama masa pandemi Covid-19. Penelitian awal tentang Produk " $\mathrm{X}$ " ini telah dilakukan dengan sampel mahasiswa sebanyak 144 orang dari berbagai program studi. Selanjutnya dilakukan analisis data kuantitatif untuk mengetahui pengaruh variabel-variabel Pengenalan, Penggunaan, dan Pengakuan Manfaat, dalam bauran Tingkat Keyakinan Produk "X", terhadap Rekomendasi Produk "X". Hasil penghitungan menunjukkan Koefisien Determinasi sebesar 0,620 dengan nilai F hitung 75,996 (Sig. 0.000). Kesimpulan sementara yang dapat diberikan adalah bahwa variabel Tingkat Keyakinan Penggunaan Produk " $\mathrm{X}$ " berpengaruh secara signifikan terhadap Rekomendasi Produk "X". Penelitian awal dengan menggunakan pendekatan kuantitatif ini masih belum bisa memberi penjelasan secara konseptual proses keterlibatan konsumen dalam membentuk persepsi manfaat terhadap kebaruan Produk "X".

Pertimbangan ini menjadi landasan melakukan penelitian lanjutan dengan menggunakan pendekatan gabungan kuantitatif-kualitatif (Harrison and Reilly, 2011; Elliot, 2018; Drisko and Maschi, 2016; Gheyle and Yacobs, 2017) dalam sudut pandang riset interpretatif (Wright and Losekoot, 2012). Oleh karenanya, rumusan masalah dalam penelitian ini adalah bagaimana konsepsi persepsi manfaat 
dapat dijelaskan melalui proses keterlibatan konsumen untuk melihat (to see), merasakan (to feel), mengalami (to experience), dan merekomendasi (to recommend) kebaruan Produk "X". Dari sisi praktis, penelitian ini diharapkan memberi kontribusi terhadap: (1) Teori Persepsi-Manfaat (Perceived-Benefit); (2) Teori Keterlibatan Konsumen (Consumer Involvement); serta (3) Teori Kebaruan Produk (Product Newness).

\section{TINJAUAN PUSTAKA}

Cummins et al. (2014) menyebutkan karakteristik konsumen dalam konteks online sebagai konsumen pembelajar (learning consumer) yakni konsumen yang keseluruhan perilaku kognitifnya didominasi aktivitas memproses dan merespons berbagai macam jenis tayangan yang membawa pesan-pesan menarik (attractive) secara khusus bagi tujuan menarik minat beli. Dalam konteks online, rekayasa media dilakukan di mana tampilan-tampilan dalam tayangan dibuat sedemikian rupa sehingga menarik untuk dilihat (to be seen), mampu dirasakan dan dialami secara emosional (to experience), serta memotivasi untuk melakukan tindakan tertentu. Salah satunya adalah perilaku konsumen media sosial online yang sangat dipengaruhi oleh persepsi kebaruan, yakni media sosial sarana baru menjalin relasi sosial (Wang, 2017). Proses tersebut merupakan bagian dari upaya atas keterlibatan konsumen untuk mengenali (to familiarize) produk. Zaichkowsky (1986) dalam Lin et al. (2013) mendefinisikan keterlibatan produk sebagai persepsi seseorang terhadap objek tertentu karena kebutuhan, nilai, serta minat sebelumnya. Keterlibatan dihubungkan dengan motivasi untuk memproses informasi.

Michaelidou and Dibb (2008) menyebutkan tiga bentuk keterlibatan dalam konteks perilaku konsumen, yaitu keterlibatan intens, keterlibatan situasional, serta keterlibatan responsif. Keterlibatan intens menunjukkan kemelekatan jangka panjang individu terhadap kelas produk tertentu yang dimanifestasikan melalui upaya-upaya untuk mencari informasi secara lebih luas, pengetahuan merek, serta komitmen terhadap merek. Keterlibatan situasional merupakan fenomena jangka pendek di mana individu terlibat dalam sebuah situasi pengambilan keputusan pembelian. Sedangkan keterlibatan responsif menggambarkan perilaku tertentu di mana individu terlibat dalam sebuah situasi yang dimanifestasikan melalui perhatian, sadar akan harga, serta peka terhadap nilai beda merek.

Keterlibatan sebagai partisipasi konsumen (consumer involvement) merupakan segenap tindakan yang dilakukan baik secara sadar ataupun tidak untuk menghubungkan produk dengan harapan yang dimiliki. Konsumen sebagai makhluk ekonomi memiliki rasionalitas untuk mencari produk menurut kebutuhan (needs) serta keinginannya (wants). Penelitian yang dilakukan oleh Cruz et al. (2017) menyebutkan bagaimana tingkatan keterlibatan itu dipengaruhi oleh kebutuhan konsumen terhadap tipe produk tertentu. Keterlibatan konsumen tinggi pada produk-produk yang bersifat hedonistis (hedonic products). Sebaliknya, pada produk-produk yang bersifat bernilai guna (utilitarian products), keterlibatan konsumen cederung rendah. Rasionalitas ini memberikan wacana manfaat ataupun nilai produk. Keterlibatan terkait dengan manfaat produk. 
Menurut Samadi dan Gharleghi (2015), persepsi manfaat dalam konteks online terbentuk ketika konsumen menemukan sejumlah keunggulan. Sedangkan Forsythe et al. (2006) dalam Samadi dan Gharleghi (2015) menyebutkan persepsi manfaat sebagai replikasi terhadap keuntungan yang diperoleh pelanggan. Kim et al. (2008) dalam Samadi dan Gharleghi (2015) menyatakan persepsi manfaat sebagai keyakinan konsumen menemukan kemudahan. Dengan demikian dalam kebaruan produk, perilaku konsumen konteks online (Cummins et al., 2014) menempatkan kebaruan produk sebagai objek pembelajaran di mana terjadi respons terhadap sesuatu yang baru, berbeda, dan menarik dengan melibatkan aktivitas pemrosesan informasi, yaitu penggunaan persepsi kognitif konsumen serta reaksi psikologi terhadap tayangan.

\section{Rerangka Teoritis}

Rerangka teoritis yang dapat dibangun melalui uraian di atas adalah bahwa setiap kebaruan produk direspons oleh konsumen dalam keterlibatannya untuk menemukan manfaat produk. Respons terhadap kebaruan produk sendiri merupakan respons terhadap sesuatu yang baru, berbeda, dan menarik. Respons ini melibatkan aktivitas pemrosesan informasi, yakni penggunaan persepsi kognitif konsumen serta reaksi psikologis dalam keseluruhan proses melihat, merasakan, mengalami, dan merekomendasi manfaat atas kebaruan produk. Rerangka teoritis penelitian seperti terlihat pada Gambar 1.

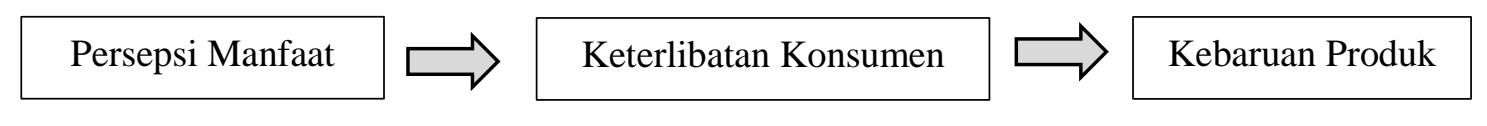

Respon terhadap sesuatu yang baru, berbeda, dan menarik dengan melibatkan aktivitas pemrosesan informasi yaitu penggunaan persepsi kognitif konsumen serta reaksi psikologis dalam keseluruhan proses melihat, merasakan, mengalami, dan merekomendasi manfaat atas kebaruan produk (Cummins et al., 2014)

\section{Gambar 1 \\ Rerangka Teoritis Penelitian}

\section{METODE PENELITIAN}

Penelitian ini bertujuan untuk mendapatkan gambaran konsepsi persepsi manfaat dalam keterlibatan konsumen terhadap kebaruan produk. Dengan teknik sampling non-probabilitas (Morissan, 2012) ditentukan jumlah responden penelitian, yaitu pengguna aktif Produk "X", sebanyak 95 orang. Peneliti menggunakan pendekatan gabungan kuantitatif-kualitatif (Harrison and Reilly, 2011; Coffey and Atkinson, 1996; Elliot, 2018; Drisko and Maschi, 2016; Gheyle and Yacobs, 2017) dalam sudut pandang riset interpretatif (Wright and Losekoot, 2012). 
Pendekatan kuantitatif digunakan untuk mengukur kekuatan variabelvariabel dalam bauran manfaat produk (product benefit) dan kebaruan produk (product newness) yaitu sebagai keseluruhan proses melihat, merasakan, mengalami, dan merekomendasi manfaat atas kebaruan produk (Cummins et al., 2014). Variabel-variabel dalam bauran Manfaat Produk (MP) meliputi: (1) Manfaat produk secara visual (MV); (2) Manfaat produk secara emosional (ME); (3) Manfaat produk secara eksperiensial (MEX); dan (4) Manfaat produk secara sosial (MS). Sedangkan variabel-variabel dalam bauran Kebaruan Produk (BP) meliputi: (1) Kebaruan produk secara visual (BV); (2) Kebaruan produk secara emosional (BE); (3) Kebaruan produk secara eksperiensial (BEX); dan (4) Kebaruan produk secara sosial (BS).

Pendekatan kuantitatif meliputi: (1) Means score, yaitu melihat besar skor rata-rata setiap variabel dalam bauran manfaat produk dan bauran kebaruan produk; (2) Korelasi Bivariate untuk mengetahui korelasi antara manfaat produk secara sosial (MS) dan kebaruan produk secara sosial (BS); (3) One-Sample Test untuk mengetahui apakah means value tertentu berbeda secara nyata atau tidak dengan rata-rata sebuah sampel; (4) Uji Regresi Berganda untuk mengetahui kekuatan hubungan parsial dan serentak antar variabel dalam bauran Manfaat Produk (MP) dan bauran Kebaruan Produk (BP).

Pendekatan kualitatif Analisis Konten dilakukan menggunakan persyaratan prinsip-prinsip inferensial (Drisko and Maschi, 2016; Gheyle and Jacobs, 2017), yaitu: (1) Inferential content analysis (analisis konten yang melibatkan penarikan inferensi); (2) Konstruk analitis (gambaran operasional pengetahuan mengenai saling ketergantungan antara data narasi partisipan "Apa yang aku ketahui mengenai manfaat atas kebaruan Produk " $X$ "?" dan konteks respons terhadap sesuatu yang baru, berbeda, dan menarik dengan melibatkan aktivitas pemrosesan informasi yaitu penggunaan persepsi kognitif konsumen serta reaksi psikologis dalam keseluruhan proses melihat, merasakan, mengalami, dan merekomendasi manfaat (nilai) atas kebaruan produk (Cummins et al., 2014). Penerapan Analisis Konten-1 berupa pemetaan konseptual (conceptual mapping) kata-kata (words) dan kata-kata pendukung (supported words) yang dapat dikategorikan ke dalam konsep persepsi manfaat, keterlibatan konsumen, dan kebaruan produk untuk menemukan Tema-1. Sedangkan Analisis Konten-2 berupa identifikasi struktur narasi responden melalui kata-kata (words) dan kata-kata pendukung (supported words) yang dapat dikategorikan ke dalam Pre-purchase Stage, Service Encounter Stage, dan Post-encounter Stage (Lovelock et al., 2011) untuk menemukan Tema-2.

\section{HASIL PENELITIAN DAN PEMBAHASAN Pendekatan kualitatif}

Pendekatan kualitatif yang diterapkan adalah analisis konten (Drisko and Maschi, 2016; Gheyle and Jacobs, 2017). Analisis konten dilakukan terhadap tiga narasi partisipan dalam menjawab pertanyaan "Apa yang aku ketahui mengenai manfaat atas kebaruan Produk " $X$ "?". Hasil tabulasi disajikan seperti terlihat pada Tabel 1. 
Tabel 1

Tabulasi Analisis Konten

\begin{tabular}{|c|c|c|c|c|}
\hline Partisipan & $\begin{array}{c}\text { Analisis } \\
\text { Konten }\end{array}$ & Kata/Kelompok kata & Deskripsi & Tema \\
\hline $\mathrm{AH}$ & 1 & $\begin{array}{l}\text { kebingungan dalam } \\
\text { penggunaannya, lama-kelamaan, } \\
\text { mulai terbiasa (Konsep = } \\
\text { Keterlibatan); mudah dalam } \\
\text { pembelajaran online, agar tidak } \\
\text { telat absen, mempermudah ketika } \\
\text { perkuliahan (Konsep = } \\
\text { Manfaat/Kemudahan); sudah } \\
\text { lengkap, langsung men-download } \\
\text { (Konsep = Manfaat/ } \\
\text { Kelengkapan); hanya memberi } \\
\text { waktu } 5 \text { menit, memakan waktu } \\
\text { yang lama (Konsep = } \\
\text { Kebaruan/Risiko pemborosan } \\
\text { waktu). } \\
\text { Keywords: } \\
\text { penggunaannya, pembelajaran } \\
\text { online, lengkap, lama. }\end{array}$ & $\begin{array}{l}\text { Manfaat dijelaskan } \\
\text { sebagai kemudahan } \\
\text { dan kelengkapan. } \\
\text { Keterlibatan } \\
\text { merupakan tindakan } \\
\text { penggunaan produk } \\
\text { secara langsung } \\
\text { sebagai sebuah proses } \\
\text { penyesuaian dengan } \\
\text { pengorbanan dan } \\
\text { risiko tertentu. } \\
\text { Kebaruan merupakan } \\
\text { persoalan rentang } \\
\text { waktu di mana } \\
\text { konsumen mulai } \\
\text { menggunakan produk } \\
\text { sampai dengan ketika } \\
\text { produk dapat diterima } \\
\text { karena manfaatnya } \\
\text { telah dikenali. }\end{array}$ & $\begin{array}{l}\text { Pengenalan } \\
\text { kemudahan dan } \\
\text { kelengkapan } \\
\text { produk dalam } \\
\text { sebuah masa } \\
\text { penyesuaian } \\
\text { dengan rentang } \\
\text { waktu tertentu. }\end{array}$ \\
\hline $\mathrm{AH}$ & 2 & $\begin{array}{l}\text { kebingungan dalam } \\
\text { penggunaannya, lama-kelamaan, } \\
\text { mulai terbiasa (Tahap Pre- } \\
\text { Purchase); mudah dalam } \\
\text { pembelajaran online, agar tidak } \\
\text { telat absen, mempermudah ketika } \\
\text { perkuliahan, sudah lengkap, } \\
\text { langsung men-download (Tahap } \\
\text { Service Encounter); hanya } \\
\text { memberi waktu } 5 \text { menit, memakan } \\
\text { waktu yang lama (Tahap Post- } \\
\text { Purchase). }\end{array}$ & $\begin{array}{l}\text { Interaksi dalam } \\
\text { keterlibatan konsumen } \\
\text { membutuhkan waktu } \\
\text { yang cukup. Manfaat } \\
\text { dapat dikenali dengan } \\
\text { mudah pada saat } \\
\text { produk digunakan. } \\
\text { Pengguna } \\
\text { menyampaikan } \\
\text { keluhan sebagai } \\
\text { kesimpulan } \\
\text { penggunaan produk. }\end{array}$ & $\begin{array}{l}\text { Pengalaman } \\
\text { kebaruan produk } \\
\text { sebagai kebiasaan } \\
\text { penggunaan } \\
\text { produk dengan } \\
\text { manfaat yang } \\
\text { mampu dikenali } \\
\text { melalui } \\
\text { pengorbanan } \\
\text { berupa risiko } \\
\text { pemborosan } \\
\text { waktu }\end{array}$ \\
\hline & & $\begin{array}{l}\text { Keywords: } \\
\text { kebingungan, mempermudah, } \\
\text { memakan waktu. }\end{array}$ & & \\
\hline $\mathrm{CM}$ & 1 & $\begin{array}{l}\text { awalnya bingung, dengan } \\
\text { berjalannya waktu }(\mathbf{K o n s e p}= \\
\text { Keterlibatan); sangat membantu, } \\
\text { dapat melihat kapan saya } \\
\text { mengumpulkan tugas, mudah }\end{array}$ & $\begin{array}{l}\text { Manfaat dijelaskan } \\
\text { sebagai kemudahan } \\
\text { dan kepraktisan. } \\
\text { Keterlibatan } \\
\text { merupakan sebuah }\end{array}$ & $\begin{array}{l}\text { Pengenalan } \\
\text { kemudahan dan } \\
\text { kepraktisan } \\
\text { produk dalam } \\
\text { sebuah proses }\end{array}$ \\
\hline
\end{tabular}




\begin{tabular}{|c|c|c|c|c|}
\hline & & $\begin{array}{l}\text { mengakses materi }(\text { Konsep }= \\
\text { Manfaat/Kemudahan); dilatih } \\
\text { menjadi disiplin, praktis dalam } \\
\text { melakukan presensi }(\text { Konsep }= \\
\text { Manfaat/Kepraktisan); semenit } \\
\text { saja telat saat meng-upload, } \\
\text { konsekuensinya saya tidak } \\
\text { mendapatkan nilai UTS/UAS } \\
\text { (Konsep = Kebaruan/ } \\
\text { Konsekuensi). } \\
\\
\text { Keywords: } \\
\text { bingung, membantu, dilatih, } \\
\text { konsekuensinya. }\end{array}$ & $\begin{array}{l}\text { proses yang } \\
\text { memerlukan waktu. } \\
\text { Keterlibatan berkaitan } \\
\text { dengan pemerolehan } \\
\text { pengetahuan } \\
\text { mengenai produk } \\
\text { yang akan semakin } \\
\text { mendalam dan } \\
\text { lengkap mengikuti } \\
\text { waktu. Kebaruan } \\
\text { merupakan persoalan } \\
\text { negosiasi antara } \\
\text { risiko kerugian } \\
\text { (ketidakbermanfaatan) } \\
\text { dengan harapan akan } \\
\text { manfaat tertentu. }\end{array}$ & $\begin{array}{l}\text { pemerolehan } \\
\text { pengetahuan } \\
\text { dengan resiko. }\end{array}$ \\
\hline CM & 2 & $\begin{array}{l}\text { awalnya bingung, dengan } \\
\text { berjalannya waktu (Tahap pre- } \\
\text { purchase); sangat membantu, } \\
\text { dapat melihat kapan saya } \\
\text { mengumpulkan tugas, mudah } \\
\text { mengakses materi, dilatih menjadi } \\
\text { disiplin, praktis dalam melakukan } \\
\text { presensi (Tahap service } \\
\text { encounter); semenit saja telat saat } \\
\text { meng-upload, konsekuensinya saya } \\
\text { tidak mendapatkan nilai UTS/UAS } \\
\text { (Tahap post-purchase). } \\
\text { Keywords: } \\
\text { awalnya, praktis, tidak } \\
\text { mendapatkan. }\end{array}$ & $\begin{array}{l}\text { Proses pengenalan } \\
\text { produk diawali } \\
\text { dengan sesuatu yang } \\
\text { tidak menyenangkan. } \\
\text { Proses berlangsung } \\
\text { sampai manfaat } \\
\text { praktis ditemukan. } \\
\text { Kesan kekhawatiran } \\
\text { terjadinya sesuatu } \\
\text { yang tidak diinginkan } \\
\text { sebagai sebuah risiko } \\
\text { atas manfaat yang } \\
\text { diperoleh. }\end{array}$ & $\begin{array}{l}\text { Pengalaman } \\
\text { kebaruan produk } \\
\text { sebagai sebuah } \\
\text { proses penuh } \\
\text { tantangan dengan } \\
\text { manfaat praktis } \\
\text { melalui } \\
\text { pengorbanan } \\
\text { kegagalan. }\end{array}$ \\
\hline $\mathrm{SS}$ & 1 & $\begin{array}{l}\text { mencoba mempelajari, mencoba } \\
\text { untuk belajar (Konsep = } \\
\text { Keterlibatan); fitur yang beragam } \\
\text { (Konsep = Manfaat/ } \\
\text { Keberagaman); bisa } \\
\text { mempermudah, membantu proses } \\
\text { pembelajaran (Konsep = } \\
\text { Manfaat/Kemudahan); waktu } \\
\text { yang sedikit lama, membutuhkan } \\
\text { waktu lebih (Konsep = } \\
\text { Kebaruan/Risiko pemborosan } \\
\text { waktu). } \\
\text { Keywords: } \\
\text { mencoba, beragam, pembelajaran, } \\
\text { sedikit lama. }\end{array}$ & $\begin{array}{l}\text { Manfaat dijelaskan } \\
\text { sebagai ketersediaan } \\
\text { berbagai macam fitur. } \\
\text { Keterlibatan } \\
\text { merupakan } \\
\text { kesempatan untuk } \\
\text { belajar. Kebaruan } \\
\text { merupakan persoalan } \\
\text { risiko penggunaan } \\
\text { waktu yang tidak } \\
\text { efisien. }\end{array}$ & $\begin{array}{l}\text { Pengenalan } \\
\text { ketersediaan } \\
\text { produk dalam } \\
\text { sebuah } \\
\text { pembelajaran } \\
\text { dengan risiko } \\
\text { ketidakefisienan } \\
\text { waktu. }\end{array}$ \\
\hline
\end{tabular}




\begin{tabular}{|c|c|c|c|c|}
\hline SS & 2 & $\begin{array}{l}\text { mencoba mempelajari, mencoba } \\
\text { untuk belajar (Tahap pre- } \\
\text { purchase); fitur yang beragam, } \\
\text { bisa mempermudah, membantu } \\
\text { proses pembelajaran (Tahap } \\
\text { service encounter); waktu yang } \\
\text { sedikit lama, membutuhkan waktu } \\
\underline{\text { lebih (Tahap post-purchase). }} \\
\underline{\text { Keywords: }} \\
\text { mempelajari, membantu, waktu } \\
\text { lebih. }\end{array}$ & $\begin{array}{l}\text { Proses meyakinkan } \\
\text { diri untuk terus } \\
\text { berusaha menemukan } \\
\text { manfaat termasuk } \\
\text { kemungkinan untuk } \\
\text { mengalami kerugian } \\
\text { waktu. }\end{array}$ & $\begin{array}{l}\text { Pengalaman } \\
\text { kebaruan produk } \\
\text { sebagai sebuah } \\
\text { pembelajaran } \\
\text { dengan manfaat } \\
\text { kemudahan } \\
\text { melalui } \\
\text { pengorbanan } \\
\text { waktu. }\end{array}$ \\
\hline
\end{tabular}

Tabel 1 di atas menunjukkan bagaimana konsumen melewati proses pengenalan produk dengan upaya sedemikian rupa di mana terdapat kesediaan menanggung sebuah risiko. Risiko dinyatakan dalam narasi partisipan sebagai ketidaknyamanan yang dapat ditoleransi (tolerable risk) terutama ketika harus mempelajari hal-hal baru. Selanjutnya dilakukan penggabungan Tema-1 dan Tema-2 sebagaimana disajikan dalam diagram pada Gambar 2.

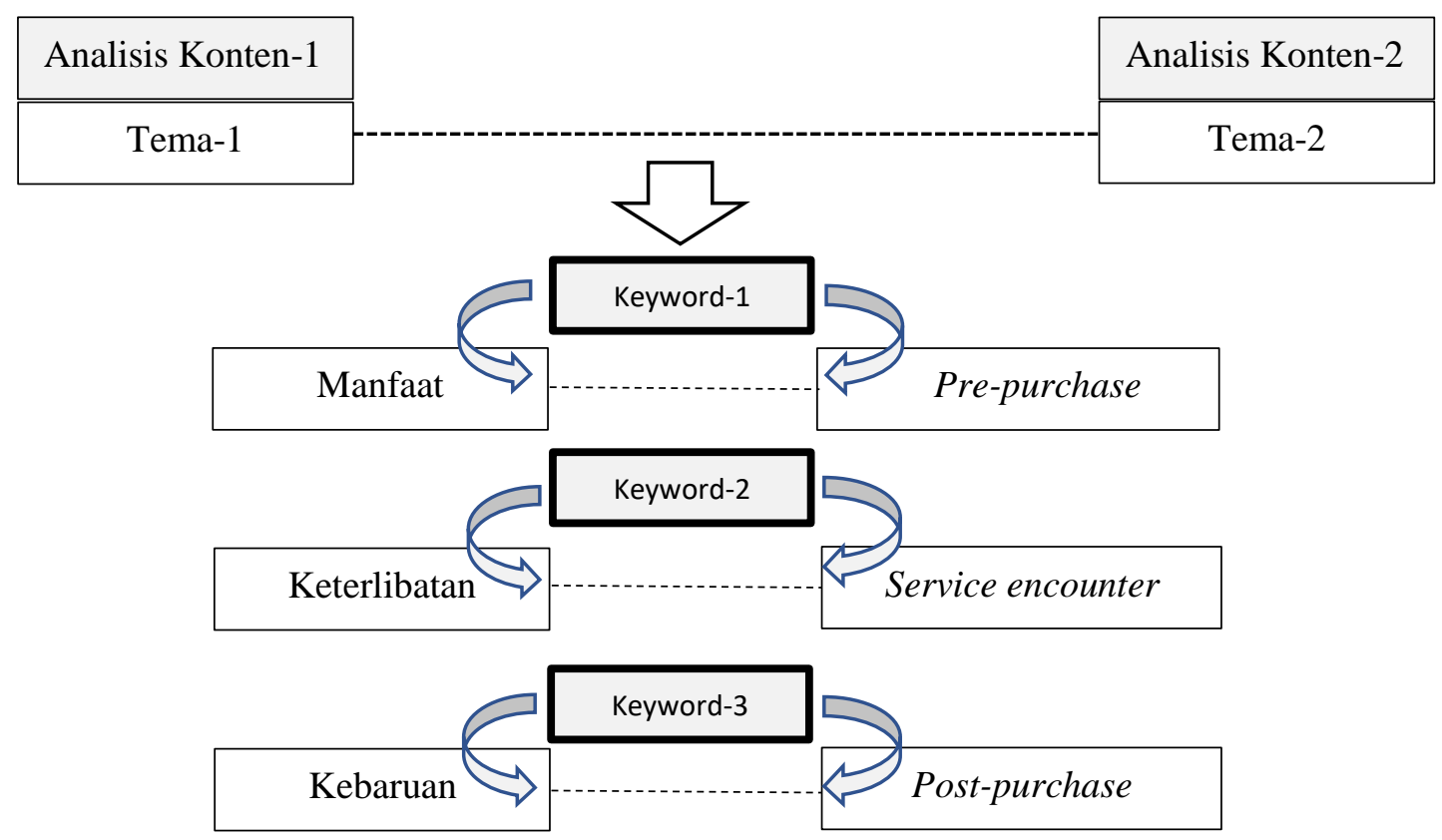

Gambar 2

Penggabungan Tema-1 dan Tema-2

Pada tahap pre-purchase konsumen mengenali kebutuhan, melakukan pencarian informasi, sekaligus evaluasi terhadap sejumlah alternatif untuk memutuskan apakah pembelian suatu layanan akan dilakukan. Manfaat menjadi atribut penting dalam tahap ini. Konsumen mengevaluasi manfaat produk dan 
menghubungkan dengan kebutuhan yang muncul. Tahap service encounter merupakan tahap kontak langsung konsumen dengan produk layanan. Keterlibatan menjadi bagian di dalam tahap tersebut di mana konsumen secara aktif mencoba untuk memaksimalkan interaksinya dengan produk layanan. Konsumen menggunakan manfaat yang telah dikenali untuk memenuhi kebutuhannya. Sedangkan tahap post-purchase menjelaskan bagaimana konsumen melakukan penilaian kinerja layanan yang telah dialami dan membandingkan dengan harapan sebelumnya. Di dalam tahap ini, konsumen menilai apakah kebaruan produk memiliki relevansi dengan manfaat yang diharapkan (Cruz et al., 2017; Samadi, 2015; Lin et al, 2013; Lovelock et al, 2011).

Melalui penggabungan konsep manfaat dan pre-purchase dapat diketahui rasionalisasi latar belakang produk, sekaligus gambaran umum harapan (expectation) manfaat (Keyword-1: Manfaat yang diharapkan). Penggabungan konsep keterlibatan dan service encounter memberikan gambaran penggunaan produk melalui pengalaman dimana konsumen menjumpai berbagai kesulitan termasuk kendala teknis (Keyword-2: Pengalaman pengenalan). Sedangkan penggabungan konsep kebaruan dan post-purchase menegaskan bagaimana konsumen menyimpulkan pengalaman penggunaan produk dengan kebaruan yang dapat diterima dan dikenali sebagai risiko (Keyword-3: Risiko yang ditoleransi).

\section{Pendekatan kuantitatif}

Pendekatan kuantitatif meliputi: (1) Means Score, yaitu melihat besar skor rata-rata setiap variabel dalam bauran manfaat produk dan bauran kebaruan produk; (2) Korelasi Bivariate untuk mengetahui korelasi antar variabel dalam bauran Manfaat Produk (MP) dan bauran Kebaruan Produk (BP); (3) One Sample t-Test untuk mengetahui apakah means value tertentu berbeda secara nyata atau tidak dengan rata-rata sebuah sampel; (4) Uji Regresi Berganda untuk mengetahui kekuatan hubungan parsial dan serentak antar variabel dalam bauran Manfaat Produk (MP) dan bauran Kebaruan Produk (BP). Pendekatan kuantitatif Means Score dan One Sample Test diterapkan dengan melihat besar skor rata-rata variabel dalam bauran Manfaat Produk dan bauran Kebaruan Produk sebagaimana terlihat pada Tabel 2 dan Tabel 3.

Tabel 2

Means Score Variabel Bauran Manfaat Produk (MP) dan Kebaruan Produk (BP)

\begin{tabular}{|c|l|c|}
\hline No. & \multicolumn{1}{|c|}{ Variabel bauran Manfaat Produk } & Means Score \\
\hline 1 & Manfaat produk secara visual (MV) & 4,46 \\
\hline 2 & Manfaat produk secara emosional (ME) & 4,43 \\
\hline 3 & Manfaat produk secara eksperiensial (MEX) & 4,46 \\
\hline 4 & Manfaat produk secara sosial (MS) & 4,28 \\
\hline No. & Variabel bauran kebaruan produk & Means Score \\
\hline 1 & Kebaruan produk secara visual (BV) & 4,53 \\
\hline 2 & Kebaruan produk secara emosional (BE) & 4,47 \\
\hline 3 & Kebaruan produk secara eksperiensial (BEX) & 4,51 \\
\hline 4 & Kebaruan produk secara sosial (BS) & 4,16 \\
\hline
\end{tabular}


Tabel 3

One Sample Test Variabel Bauran Manfaat Produk (MP) dan Kebaruan Produk (BP)

\begin{tabular}{|c|c|c|c|}
\hline Test-value & Variabel & $\mathbf{t}$ & Sig. (2-tailed) \\
\hline \multirow[t]{8}{*}{$5,00 *)$} & Manfaat produk secara visual (MV) & $-7,511$ & 0,000 \\
\hline & Manfaat produk secara emosional (ME) & $-8,163$ & 0,000 \\
\hline & $\begin{array}{l}\text { Manfaat produk secara eksperiensial } \\
(\mathrm{MEX})\end{array}$ & $-7,511$ & 0,000 \\
\hline & Manfaat produk secara sosial (MS) & $-9,094$ & 0,000 \\
\hline & Kebaruan produk secara visual (BV) & $-6,350$ & 0,000 \\
\hline & Kebaruan produk secara emosional (BE) & $-6,918$ & 0,000 \\
\hline & $\begin{array}{l}\text { Kebaruan produk secara eksperiensial } \\
\text { (BEX) }\end{array}$ & $-6,912$ & 0,000 \\
\hline & Kebaruan produk secara sosial (BS) & $-8,974$ & 0,000 \\
\hline Test-value & Variabel & $\mathbf{t}$ & Sig. (2-tailed) \\
\hline \multirow[t]{8}{*}{$4,50 *)$} & Manfaat produk secara visual (MV) & $-0,515$ & 0,607 \\
\hline & Manfaat produk secara emosional (ME) & $-0,983$ & 0,328 \\
\hline & $\begin{array}{l}\begin{array}{l}\text { Manfaat produk secara eksperiensial } \\
(\mathrm{MEX})\end{array} \\
\end{array}$ & $-0,515$ & 0,607 \\
\hline & Manfaat produk secara sosial (MS) & $-2,742$ & 0,007 \\
\hline & Kebaruan produk secara visual (BV) & 0,353 & 0,725 \\
\hline & Kebaruan produk secara emosional (BE) & $-0,346$ & 0,730 \\
\hline & $\begin{array}{l}\text { Kebaruan produk secara eksperiensial } \\
\text { (BEX) }\end{array}$ & 0,074 & 0,942 \\
\hline & Kebaruan produk secara sosial (BS) & $-3,646$ & 0,000 \\
\hline Test-value & Variabel & $\mathbf{t}$ & Sig. (2-tailed) \\
\hline \multirow[t]{8}{*}{$4,00 *)$} & Manfaat produk secara visual (MV) & 6,480 & 0,000 \\
\hline & Manfaat produk secara emosional (ME) & 6,197 & 0,000 \\
\hline & $\begin{array}{l}\text { Manfaat produk secara eksperiensial } \\
\text { (MEX) }\end{array}$ & 6,480 & 0,000 \\
\hline & Manfaat produk secara sosial (MS) & 3,611 & 0,000 \\
\hline & Kebaruan produk secara visual (BV) & 7,056 & 0,000 \\
\hline & Kebaruan produk secara emosional (BE) & 6,226 & 0,000 \\
\hline & $\begin{array}{l}\text { Kebaruan produk secara eksperiensial } \\
\text { (BEX) }\end{array}$ & 7,059 & 0,000 \\
\hline & Kebaruan produk secara sosial (BS) & 1,683 & 0,096 \\
\hline
\end{tabular}

*) 5,00 = Sangat setuju; 4,50 = Cenderung sangat setuju; 4,00 = Setuju

Dari Tabel 2 diketahui skor rata-rata variabel dalam bauran Manfaat Produk dan bauran Kebaruan Produk di atas 4 (= setuju). Skor ini kemudian dibandingkan dengan skor 5 (= sangat setuju), skor 4.5 (= cenderung sangat setuju), dan skor 4 (= setuju) menggunakan One Sample Test (Tabel 3).

Pada test-value 5 dan 4 (Tabel 3) diketahui seluruh variabel mempunyai tingkat signifikansi dibawah $0,01 . \mathrm{H}_{0}$ yang menyatakan tidak ada perbedaan antara Means Score variabel bauran Manfaat Produk dan bauran Kebaruan Produk dengan skor 5 ditolak. Kecuali Kebaruan Produk secara sosial (BS) pada test-value 4 yang memiliki tingkat signifikansi sedikit di atas $0,01(0,096)$. Ini membuktikan skor rata-rata variabel dalam bauran Manfaat Produk dan bauran Kebaruan Produk tidak dapat dikatakan sama dengan skor 5. Sedangkan pada test-value 4,5 diketahui seluruh variabel (kecuali BS) memiliki tingkat signifikansi lebih besar daripada 
$0,01 . \mathrm{H}_{0}$ yang menyatakan tidak ada perbedaan antara Means Score variabel bauran Manfaat Produk dan bauran Kebaruan Produk dengan skor 5 tidak dapat ditolak. Ini menunjukkan bahwa terdapat kecenderungan terjadi kondisi ideal di mana konsumen menggunakan potensi sumber daya rasionalitas ekonomis secara maksimal dalam keterlibatannya membentuk persepsi manfaat atas sebuah kebaruan produk.

Tabel 4 berikut ini menyajikan hasil korelasi antara variabel dalam bauran Manfaat Produk dan bauran Kebaruan Produk.

\section{Tabel 4}

Korelasi Bivariate Variabel dalam Bauran Manfaat Produk dan Kebaruan Produk

\begin{tabular}{|l|c|c|lr|}
\hline \multicolumn{1}{|c|}{ Variabel } & $\begin{array}{l}\text { Pearson } \\
\text { correlation }\end{array}$ & Signifikansi & \multicolumn{3}{|c|}{ Interpretasi } \\
\hline MV -> BV & 0,270 & $<0,01$ & $\begin{array}{l}\text { Kebaruan dikenali manfaatnya ketika } \\
\text { melibatkan aspek visual yaitu melihat, } \\
\text { menyaksikan (to see). }\end{array}$ \\
\hline ME -> BE & 0,372 & $<0,01$ & $\begin{array}{l}\text { Kebaruan dikenali manfaatnya ketika } \\
\text { melibatkan aspek emosional yaitu merasakan } \\
\text { to feel). }\end{array}$ \\
\hline MEX -> BEX & 0,389 & $<0,01$ & $\begin{array}{l}\text { Kebaruan dikenali manfaatnya ketika } \\
\text { melibatkan aspek penggunaan yaitu } \\
\text { mengalami (to experience). }\end{array}$ \\
\hline MS -> BS & 0,709 & $<0,01$ & $\begin{array}{l}\text { Kebaruan dikenali manfaatnya ketika } \\
\text { melibatkan aspek sosial yaitu ketika orang lain } \\
\text { memakai, menggunakan (to recommend) }\end{array}$ \\
\hline
\end{tabular}

Korelasi Bivariate dalam Tabel 4 dipakai untuk menjelaskan keterlibatan konsumen dalam membentuk persepsi manfaat atas kebaruan produk dalam empat bentuk: (1) Kebaruan dikenali manfaatnya ketika melibatkan aspek visual yaitu melihat, menyaksikan. Manfaat atas Kebaruan Produk dikenali pada saat kebaruan itu sendiri dapat dilihat, disaksikan (to see). (2) Kebaruan dikenali manfaatnya ketika melibatkan aspek emosional yaitu merasakan. Manfaat atas Kebaruan Produk dikenali pada saat kebaruan itu dapat dirasakan (to feel). (3) Kebaruan dikenali manfaatnya ketika melibatkan aspek penggunaan yaitu mengalami (to experience). Manfaat atas Kebaruan Produk dikenali pada saat kebaruan itu dipakai, digunakan. (4) Kebaruan dikenali manfaatnya ketika melibatkan aspek sosial yaitu ketika orang lain memakai, menggunakan (to recommend). Dalam pengertian ini Manfaat Kebaruan dikenali ketika ada keinginan untuk merekomendasi produk kepada orang lain. Persepsi terhadap manfaat kebaruan terbentuk ketika ada pengakuan dari orang lain (social recognition).

Selanjutnya pada Tabel 5 dan Tabel 6 disajikan hasil Analisis Regresi Linear Berganda variabel dalam bauran Manfaat Produk (MP) dan bauran Kebaruan Produk (BP). 
Tabel 5

Hasil Analisis Regresi Linear Berganda Variabel dalam

Bauran Manfaat Produk (MP)

\begin{tabular}{|c|c|c|c|}
\hline \multicolumn{4}{|c|}{ Model: $\mathrm{Y}=0,257+0,137 \mathrm{X} 1+0,130 \times 2+0,131 X 3$} \\
\hline $\mathbf{Y}$ & \multicolumn{3}{|l|}{ Manfaat produk secara sosial (MS) } \\
\hline $\mathbf{X 1}$ & Manfaat produk secara visual (MV) & $\begin{array}{l}\mathrm{t} \text { hitung }=3,636 / \text { Sig. }= \\
0,000\end{array}$ & $\begin{array}{l}\mathrm{t} \text { tabel }=1,986 / \text { Sig. }= \\
0,05\end{array}$ \\
\hline $\mathbf{X} 2$ & Manfaat produk secara emosional (ME) & $\begin{array}{l}\mathrm{t} \text { hitung }=0,131 / \text { Sig. }= \\
0,896\end{array}$ & $\begin{array}{l}\text { t tabel }=1,986 / \text { Sig. }= \\
0,05\end{array}$ \\
\hline $\mathbf{X 3}$ & $\begin{array}{l}\text { Manfaat produk secara eksperiensial } \\
(\text { MEX) }\end{array}$ & $\begin{array}{l}\mathrm{t} \text { hitung }=2,965 / \text { Sig. }= \\
0,004\end{array}$ & $\begin{array}{l}\mathrm{t} \text { tabel }=1,986 / \text { Sig. }= \\
0,05\end{array}$ \\
\hline $\mathbf{R}^{2}$ & \multicolumn{3}{|l|}{0,603} \\
\hline $\mathbf{F}$ & \multicolumn{3}{|c|}{$\begin{array}{l}46,005 \text { (Sig. } 0,000<0,01) \mathrm{F} \text { tab }(3,91): 2,705 . \mathrm{F}_{\text {hitung }}>\mathrm{F}_{\text {tabel }}: \mathrm{MV}, \mathrm{ME}, \mathrm{MEX} \text { secara serempak } \\
\text { mempengaruhi MS. }\end{array}$} \\
\hline $\mathbf{N}$ & \multicolumn{3}{|l|}{95} \\
\hline
\end{tabular}

*) Telah dilakukan Uji Reliabilitas dengan nilai Cronbach's Alpha 0,893, dan Uji Validitas dengan tingkat signifikansi dibawah 0,01

Variabel Manfaat produk secara visual (MV), Manfaat produk secara emosional (ME), dan Manfaat produk secara eksperiensial (MEX) dalam bauran Manfaat Produk (MP) berpengaruh secara serempak terhadap Manfaat produk secara sosial (MS), ditunjukkan dari nilai $F_{\text {hitung }} 46,005$ (Sig. $<0,000$ ) lebih besar daripada $F_{\text {tabel }}$ 2,705 . Kontribusi variabel independen terhadap variabel terikat sebesar 60,3\%. Dengan demikian kontribusi variabel-variabel Manfaat produk secara visual (MV), Manfaat produk secara emosional (ME), dan Manfaat produk secara eksperiensial (MEX) dalam mempengaruhi secara serempak terhadap variabel Manfaat produk secara sosial (MS) sebesar 60,3\%. Kekuatan pengaruh secara serempak variabelvariabel independen terhadap variabel dependen terbukti lebih signifikan dibandingkan dengan pengaruh secara parsial. Tingkat signifikansi nilai $\mathrm{R}^{2}$ ini menunjukkan tingginya keterlibatan konsumen untuk membentuk persepsi Manfaat Produk (dalam keseluruhan perilakunya untuk melihat, mengalami, dan menggunakan produk).

\section{Tabel 6}

\section{Hasil Analisis Regresi Linear Berganda Variabel dalam Bauran Kebaruan Produk (BP)}

\begin{tabular}{|c|c|c|c|}
\hline \multicolumn{4}{|c|}{ Model: $Y=0,962+0,345 X 1+0,446 \times 2-0,080 X 3$} \\
\hline $\mathbf{Y}$ & \multicolumn{3}{|l|}{ Kebaruan produk secara sosial (BS) } \\
\hline $\mathbf{X 1}$ & Kebaruan produk secara visual (BV) & $\begin{array}{l}\text { t hitung }=1,708 / \text { Sig. }= \\
0,091\end{array}$ & $\begin{array}{l}\text { t tabel }=1,986 / \text { Sig. }= \\
0,05\end{array}$ \\
\hline $\mathbf{X 2}$ & $\begin{array}{l}\text { Kebaruan produk secara emosional } \\
\text { (BE) }\end{array}$ & $\begin{array}{l}\mathrm{t} \text { hitung }=2,270 / \text { Sig. }= \\
0,026\end{array}$ & $\begin{array}{l}\mathrm{t} \text { tabel }=1,986 / \text { Sig. }= \\
0,05\end{array}$ \\
\hline $\mathbf{X 3}$ & $\begin{array}{l}\text { Kebaruan produk } \\
\text { eksperiensial }(\mathrm{BEX})\end{array}$ & $\begin{array}{l}\text { thitung }=-0,388 / \text { Sig. }= \\
0,699\end{array}$ & $\begin{array}{l}\mathrm{t} \text { tabel }=1,986 / \text { Sig. }= \\
0,05\end{array}$ \\
\hline $\mathbf{R}^{\mathbf{2}}$ & \multicolumn{3}{|l|}{0,306} \\
\hline $\mathbf{F}$ & \multicolumn{3}{|c|}{$\begin{array}{l}\text { 13,389 (Sig. 0,000 < 0,01) F tab }(3,91): 2,705 . \mathrm{F}_{\text {hitung }}>\mathrm{F} \text { tabel }: \mathrm{BV}, \mathrm{BE}, \mathrm{BEX} \text { secara } \\
\text { serempak mempengaruhi BS. }\end{array}$} \\
\hline $\mathbf{N}$ & \multicolumn{3}{|l|}{95} \\
\hline
\end{tabular}


Variabel Kebaruan produk secara visual (BV), Kebaruan produk secara emosional (BE) dan Kebaruan produk secara eksperiensial (BEX) dalam bauran Kebaruan Produk (BP) berpengaruh secara serempak terhadap Kebaruan produk secara sosial (BS). Ini ditunjukkan dari nilai $F_{\text {hitung }}$ sebesar 13,389 (Sig. < 0,000) lebih besar daripada $F_{\text {tabel }} 2,705$. Kontribusi pengaruh variabel independen terhadap variabel terikat (nilai $\mathrm{R}^{2}=0,306$ ) sebesar $30.6 \%$. Kontribusi variabel-variabel Kebaruan produk secara visual (BV), dan Kebaruan produk secara eksperiensial (BEX) dalam mempengaruhi secara serempak terhadap variabel Kebaruan produk secara sosial (BS) diketahui sebesar 30,6\%. Sedangkan pengaruh parsial yang signifikan dikontribusikan oleh variabel Kebaruan produk secara emosional (BE) dengan nilai thitung sebesar 2,270 (Sig 0,026<0,05).

Pengaruh secara serempak yang signifikan variabel independen terhadap variabel dependen mengindikasikan konsumen mampu melihat dan menggunakan kebaruan sebagai sesuatu yang perlu, dan oleh karenanya perlu direkomendasikan kepada orang lain. Kebaruan tersebut dapat dikenali dan digunakan sesuai dengan tingkat kebutuhan konsumen. Sedangkan pengaruh parsial variabel Kebaruan produk secara emosional (BE) mengindikasikan konsumen yang memiliki pengalaman penggunaan kebaruan produk. Kebaruan produk memberi pengalaman emosional yang signifikan kepada konsumen untuk bersedia merekomendasi kepada orang lain.

\section{Pendekatan Gabungan Kualitatif-Kuantitatif}

Melalui pendekatan gabungan kualitatif-kuantitatif dikembangkan dua konsep dasar untuk membangun pemahaman konsepsi persepsi manfaat terhadap kebaruan produk melalui keterlibatan konsumen. Pertama, konsep manfaat yang dikenali dari pengalaman (experienced-driven benefit). Konsep ini meliputi: (1) Manfaat yang diharapkan; (2) Pengalaman pengenalan; dan (3) Risiko yang ditoleransi. Kedua, konsep manfaat yang berasal dari rasionalitas ekonomi (economically rationalized benefit). Konsep ini meliputi: (1) Penggunaan sumber daya rasionalitas ekonomis secara maksimal oleh konsumen; (2) Manfaat atas kebaruan produk yang dikenali pada saat kebaruan itu sendiri dapat dilihat (to see); (3) Manfaat atas kebaruan produk yang dikenali pada saat kebaruan itu dapat dirasakan (to feel); (4) Manfaat atas kebaruan produk yang dikenali pada saat kebaruan itu dipakai; (5) Persepsi terhadap manfaat kebaruan yang terbentuk ketika ada pengakuan dari orang lain; (6) Keterlibatan konsumen yang tinggi; (7) Kesanggupan konsumen melihat dan menggunakan kebaruan sebagai sesuatu yang perlu, dan oleh karenanya perlu direkomendasikan kepada orang lain; (8) Kebaruan produk yang memberi pengalaman emosional membuat konsumen bersedia merekomendasi kepada orang lain.

Melalui penggunaan sumber daya rasionalitas ekonomi (Konsep-2.1), keterlibatan konsumen (Konsep-2.6) diwujudkan dengan mengenali dan melihat (Konsep-2.2), merasakan (Konsep-2.3), memakai (Konsep-2.4), serta merekomendasi (Konsep-2.5, Konsep-2.7, Konsep-2.8) sebagai bagian dari proses pembentukan persepsi manfaat atas kebaruan produk. Rasionalitas ekonomi dalam keterlibatan konsumen (Konsep-2.1 dan Konsep-2.3) ini juga mengarahkan 
konsumen untuk mengalami proses pengenalan produk (Konsep-2.2) dan risiko yang dapat ditoleransi (Konsep-1.3).

Pengalaman mengambil peran sentral dalam proses identifikasi manfaat pada kebaruan produk. Artinya, respons terhadap kebaruan produk didominasi oleh persepsi manfaat. Kebaruan menjadi relevan sejauh dapat memberikan manfaat praktis yang dapat dilihat dan dirasakan konsumen. Konteks pengalaman ini ekuivalen dengan tingkat keterlibatan konsumen yakni partisipasi aktif yang dilakukan dengan mengevaluasi konsistensi relevansi manfaat-kebutuhan. Pengalaman juga tidak sepenuhnya sesuai dengan yang diharapkan, tetapi disadari melalui rasionalitas ekonomi konsumen sebagai trade-off, yakni pengorbanan untuk menghasilkan sebuah nilai.

\section{SIMPULAN}

Penelitian konseptual ini mencoba menjelaskan proses terbentuknya persepsi manfaat dalam keterlibatan konsumen terhadap kebaruan produk. Prosedur pendekatan kualitatif dan kuantitatif digunakan untuk memfasilitasi terbentuknya sebuah pemahaman dasar konsepsi persepsi manfaat terhadap kebaruan produk melalui keterlibatan konsumen.

Dua konsep dasar dihasilkan, masing-masing konsep manfaat yang dikenali dari pengalaman (experienced-driven benefit) dan konsep manfaat yang berasal dari rasionalitas ekonomi (economically rationalized benefit). Kedua konsep tersebut mengindikasikan tuntutan bisnis melakukan inovasi dalam wacana kebaruan produk yang mampu membentuk persepsi manfaat melalui penggunaan secara langsung.

\section{SARAN}

Mengingat tren perkembangan lingkungan bisnis yang kompetitif, disarankan dilakukan penelitian lanjutan untuk menerapkan kedua konsep dasar tersebut dalam ruang lingkup wacana kebaruan produk yang memiliki nilai-nilai praktis dan memberi pengalaman.

\section{DAFTAR PUSTAKA}

Bloch, P. H., S. Commuri, and T. J. Arnold. 2009. Exploring The Origins of Enduring Product Involvement. Qualitative Market Research: An International Journal, Vol. 12, No. 1, pp. 49-69.

Coffey, A. and P. Atkinson. 1996. Making Sense of Qualitative Data: Complementary Research Strategies. Sage Publications, Inc.

Cruz, R. E., J. M. Leonhardt, and T. Pezzuti. 2017. Second Person Pronouns Enhance Consumer Involvement and Brand Attitude. Journal of Interactive Marketing, Vol. 39, pp. 104-116.

Cummins, S., J. W. Peltier, J. A. Schibrowsky, and A. Nill. 2014. Consumer Behavior in The Online Context. Journal of Research in Interactive Marketing, Vol. 8, No. 3, pp. 169-202. 
Dinnin, Aimee. 2009. The Appeal of Our New Stuff: How Newness Creates Value. Advances in Consumer Research, Vol. 36 eds. Ann L. McGill and Sharon Shavitt. Duluth, MN: Association for Consumer Research, pp. 261-265.

Drisko, J.W. and T. Maschi. 2016. Content Analysis. New York: Oxford University Press.

Elliott, Victoria. 2018. Thinking About The Coding Process in Qualitative Data Analysis. The Qualitative Report, Vol. 23, No. 1, pp. 2850-2861.

Gheyle, N. and T. Jacobs. 2017. Content Analysis: A Short Overview. Working Paper. December 2017, pp. 1-18.

Harrison, R. L. and T. M. Reilly. 2011. Mixed Methods Designs in Marketing Research. Qualitative Market Research: An International Journal, Vol. 14, No. 1, pp. 7-25.

Kinard, B. R. and M. L. Capella. 2006. Relationship Marketing: The Influence of Consumer Involvement on Perceived Service Benefits. Journal of Services Marketing, Vol. 20, No. 6, pp. 359-368.

Lin, C., Y. Wu, and J. V. Chen. 2013. Electronic Word-of-Mouth: The Moderating Roles of Product Involvement and Brand Image. Proceedings of 2013 International Conference on Technology Innovation and Industrial Management 29-31 May 2013, Phuket, Thailand.

Lovelock, C. H., P. Patterson, and J. Wirtz. 2011. Services Marketing. 6th Edition. Melbourne: Pearson Australian.

Martin, Neale and Kyle Morich. 2011. Unconscious Mental Processes in Consumer Choice: Toward A New Model of Consumer Behavior. Journal of Brand Management Advance Online Publication, pp. 1-23.

Michaelidou, N. and S. Dibb. 2008. Product Involvement: A new Perspective. Marketing Review, Vol. 8, No. 1, pp. 83-99.

Morissan. 2012. Metode Penelitian Survei. Jakarta: Penerbit Kencana.

Samadi, B. and B. Gharleghi. 2015. The Impact of Perceived Risks and Perceived Benefits to Improve An Online Intention Among Generation-Y in Malaysia. Asian Social Science, Vol. 11, No. 26, pp. 226-238.

Wang, Tien. 2017. Social Identity Dimensions and Consumer Behavior in Social Media. Asia Pacific Management Review, Vol. 22, pp. 45-51.

Wang, L., L. J. Jin, K. Z. Zhou, C. B. Li, and E. Yin. 2020. Does Customer Participation Hurt New Product Development Performance? Customer Role, Product Newness, and Conflict. Journal of Business Research, Vol. 109, pp. 246-259. 
Wright, N. and E. Losekoot. 2012. Interpretative Research Paradigms: Points of Difference. ECRM 9th European Conference on Research Methods in Business Management. 